\begin{tabular}{|l|l|c|l|}
\hline Eiszeitalter u. Gegenwart & 42 & $\begin{array}{c}134-145 \\
7 \text { fig., } 4 \text { tab. }\end{array}$ & Hannover 1992 \\
\hline
\end{tabular}

\title{
Stratigraphy, Geochemistry, and Paleomagnetism of Late Quaternary Bedrock and Paleosols, Karisoke Area, Virunga Mountains, Northwestern Rwanda
}

\author{
William C. Mahaney, Ronald G. V. Hancock \& René W. Barendregt *)
}

Quaternary, stratigraphy, geochemistry, palaeomagnetic research, Africa, Northwestern Rwanda, Virunga Mountains

\begin{abstract}
A surface soil and two buried paleosols, units II-III-IV (upper) and IV (lower)-V, provide important information on paleoclimate/drainage in the Virunga Mountains from drier to wetter paleoclimatic episodes of the last glaciation and middle postglacial periods. In general, the stratigraphy indicates a period of bedrock weathering, followed by episodic emplacement of tuffaceous sediments accompanied by weathering initially in a drier and perhaps colder paleoenvironment. Later, during the last glaciation (interstadial), increased stream activity emplaced alluvium, covered with a thin layer of tuff, all of which is weathered more vigorously than the underlying sediments. The surface soil (ground soil) shows comparatively less weathering and movement of mobile elements indicating the late middle to late Holocene paleoenvironment was somewhat drier and perhaps cooler compared with the early Holocene. The geochemistry of these three soils shows considerable depletion of $\mathrm{Na}, \mathrm{Ca}$, and $\mathrm{K}$ in the middle paleosol relative to the older buried paleosol and to the surface horizons. Iron is an important indicator of paleoclimate, suggesting that the middle II and III units of the upper paleosol formed under a paleoclimate wetter than today. The radiocarbon-dated middle paleosol indicates it could have been exposed to subaerial weathering from the Kalambo Interstadial $(\approx 25,000 \mathrm{yr} \mathrm{BP})$ to the middle Holocene. The total weathering in the middle unit is too advanced to have occurred during the Holocene. The relatively high concentrations of Th in local bedrock, tuffs, alluvium and slope wash indicate that it is the source of radioactivity reported by other workers in The Virunga Mountains.
\end{abstract}

*) Adresses of the authors: Prof. Dr. William C. MahaNEY, Geomorphology and Pedology Laboratory, Department of Geography, Atkinson College, York University North York, Ontario, Canada M3J 1P3. Dr. R. G. V. HANCOCK, SLOWPOKE Reactor Facility and Department of Chemical Engineering and Applied Chemistry, University of Toronto, Toronto, Ontario, Canada M 5 S 1 A 4. Prof. RENÉ W. BAREN. DREGT, Department of Geography, Lethbridge University, Lethbridge, Alberta, Canada T $1 \mathrm{~K} 3 \mathrm{M} 4$.
[Stratigraphie, Geochemie und Paläomagnetik spätquartärer Gesteine und Paläoböden im Karisoke-Gebiet der Virunga-Berge, Nordwest-Rwanda]

Kurzfassung: Ein rezenter Boden und zwei begrabene Paläoböden, Einheiten II-III-IV (oberer) und IV (unterer)-V, liefern wichtige Informationen über Paläoklima und Abflußverhältnisse in den Virunga-Bergen von trockeneren zu feuchteren paläoklimatischen Phasen des Spätglazials bis zu mittleren postglazialen Zeiten. Zusammenfassend betrachtet, weist die stratigraphische Abfolge zunächst auf eine Verwitterungsperiode des Festgesteins hin, der eine Phase folgt, in der tuffige Schichten abgelagert wurden. Die Zeit war von einer Verwitterung unter trockeneren und vielleicht kälteren Bedingungen begleitet. Später, während des letzten Glazials, kam es bei verstärkter Aktivität der Flüsse zur Sedimentation von Schwemmlandablagerungen, die von einer dünnen Tuff-Schicht überdeckt wurden. Diese Sedimente sind intensiver verwittert als die liegenden Schichten. Der rezente Boden zeigt eine vergleichsweise geringe Verwitterung mobiler Elemente, was darauf hindeutet, daß die Klimaverhältnisse im späten Mittel-Holozän und Spät-Holozän etwas trockener und vielleicht kühler waren als im FrühHolozän. Die Geochemie der drei Böden zeigt eine bedeutende Abnahme von $\mathrm{Na}$, Ca und $\mathrm{K}$ im mittleren Paläoboden im Vergleich zum älteren Paläoboden und zu den rezenten Böden. Eisen als ein wichtiger Indikator für das Paläoklima deutet darauf hin, daß die mittleren Einheiten II und III des oberen Paläobodens unter feuchteren Klimabedingungen als heute entstanden sind. Die Radiokarbon-Datierungen des mittleren Paläobodens zeigen, daß dieser Boden einer subaerischen Verwitterung vom Kalambo-Interstadial $(\approx 25000$ Jahre vor heute) bis zum Mittel-Holozän ausgesetzt war. Die gesamte Verwitterung im mittleren Abschnitt ist zu weit fortgeschritten und während des Holozäns entstanden. Die relativ hohe Konzentration von Th in den anstehenden Festgesteinen, Tuffen, Schwemmlandsedimenten und Hangrutschmassen zeigt, daß Th die Quelle der Radioaktivität ist, von der andere Autoren aus den Virunga-Bergen berichten. 


\section{Introduction}

The surficial geology and geochemistry of the Virunga Mountains in northwestern Rwanda are very poory understood (ANTRUN and MAGNEE 1983; HARRIS 1982). Of the five Rwandan volcanoes, Karisimbi $(4510 \mathrm{~m})$ is the highest and contains a complex series of lava flows which cover the largest area. Over 150 parasitic cones circle the summit area and presumably are the source of most pyroclastic sediments and rocks found around the mountain. One young lava flow (precise location unrecorded) from Karisimbi has been dated 56,000 yr by K/Ar (HARRIS 1982). The following discussion concerns the stratigraphy, geochemistry and paleomagnetism of a section on the northeastern flank of Karisimbi (Figure 1) at $3100 \mathrm{~m}$ (in the valley area between Karisimbi and Visoke).

\section{Field Area}

The Virunga Volcanoes in northwestern Rwanda (on the Zaire-Rwanda-Uganda border Figure 1), consist mainly of rocks of basaltic composition (MERCIER 1984). In some cases, thick cover over rocks of tufface- ous origin overlie the basalt; all are usually weathered to depths of 1.0 to $3.0 \mathrm{~m}$ depending on age. Surficial deposits of loess, colluvium and alluvium are often weathered into thick $(\approx 2.0 \mathrm{~m})$ brown $(10 \mathrm{YR} 4 / 4)$ colored paleosols sometimes forming compound units (e.g. similar to II A $11 \mathrm{~b}$ and II A $12 \mathrm{~b}$ horizons in Figure 2) that appear to have formed during the last glaciation when the timberline was depressed several hundred meters.

The site is located in the upper portion of the Hagenia woodland dominated by Hagenia abyssinica (COE 1967; HEDBERG 1964). The presence of a dark moorland-like paleosol, at or near the surface, that can be traced to elevations as low as $2750 \mathrm{~m}$ indicates a substantial vegetation depression. Because the thick moorland-like paleosol is similar to one observed on Mount Kenya (900 km to the east) (MAHANEY 1990), it is considered an important paleoclimatic indicator. The present-day climate is wet with mean annual precipitation at approximately $2000 \mathrm{~mm}$ (FOSSEY 1982). Evapotranspiration is unknown. The temperature in the upper Hagenia forest may approximate the mean annual temperature of $10 \pm 6^{\circ} \mathrm{C}$ at a similar altitude on Mount Kenya (MAHANEY \& BOYER 1986).

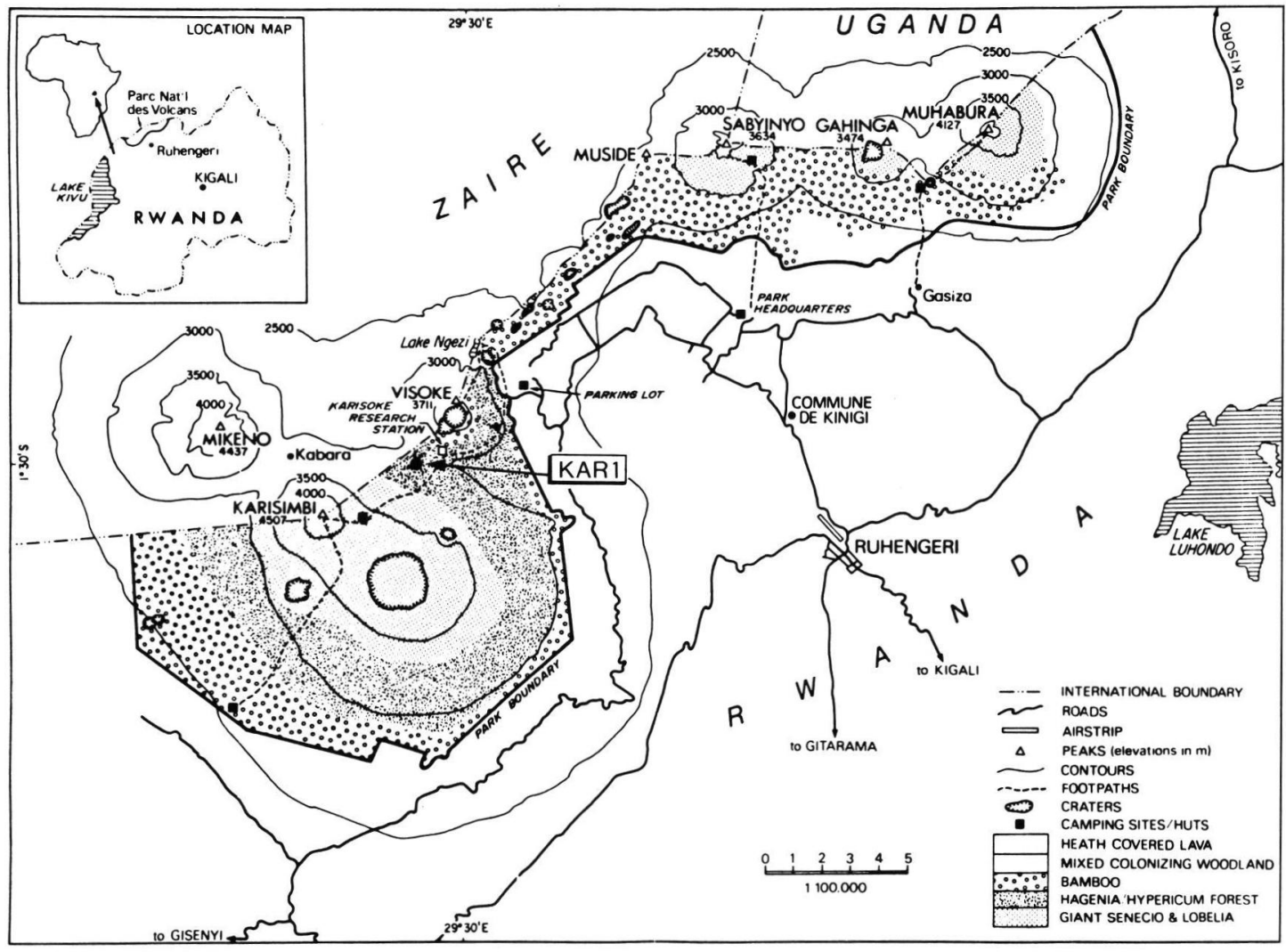

Fig. 1: Location of sampling site in the Virunga Mountains, northwestern Rwanda. 


\section{Methods}

The KAR 1 section was described using the nomenclature of the SOIL SURVEY STAFF $(1951,1975)$ and BIRKELAND (1984). Soil and sediment colors were estimated using the color chips of OYAMA \& TAKEHARA (1970). Samples were collected and dried after removing the granule and pebble size material $(>2 \mathrm{~mm})$. Particle size determinations follow the Wentworth scale (FOLK 1968) for coarse material (sand and silt) and the SOIL SURVEY STAFF (1975) for fine particles (clay). Particle sizes were determined by dry sieving for coarse material $(2 \mathrm{~mm}-63 \mu \mathrm{m})$ (DAY 1965) and by sedimentation for fines $(<63 \mu \mathrm{m})$ (BOUYOUCOS 1962). Each sample was X-rayed using Ni-filtered $\mathrm{Cu} \mathrm{K} \alpha$ radiation to determine the mineral content of the $<2 \mu \mathrm{m}$ fraction following procedures outlined by WhitTig (1965) and MAHANEY (1981). Salts were analyzed following procedures of BOWER \& WILCOX (1965). The $\mathrm{pH}$ was measured by electrode using a soil-water ratio of $1: 5$. The $<2 \mathrm{~mm}$ samples were subsampled and approximately 1 to $2 \mathrm{~g}$ was placed in small flip-top polyvials for neutron activation analysis in the SLOWPOKE nuclear reactor at the University of Toronto (HANCOCK 1978, 1984).

To determine the concentrations of $\mathrm{U}, \mathrm{Dy}, \mathrm{Ba}, \mathrm{Ti}$, $\mathrm{Mg}, \mathrm{Na}, \mathrm{V}, \mathrm{Al}, \mathrm{Mn}, \mathrm{Ca}$ and $\mathrm{K}$, which produce shortlived radioisotopes, the samples were irradiated serially for 1 minute at a neutron flux of $1.0 \times 10^{11}$ $\mathrm{n} \cdot \mathrm{cm}^{-2} \cdot \mathrm{s}^{-1}$ in the SLOWPOKE nuclear reactor at the University of Toronto. After a delay time of 19 minutes (which allows the very short-lived ${ }^{28} \mathrm{Al}$ to decay to acceptable levels), each sample was assayed using 5 minute counts with on-site gamma-ray spectrometers, as described by HANCOCK (1984). Appropriate gamma-ray peak areas were measured and the chemical concentrations calculated using the comparator method.

The samples were then batch irradiated for 16 hours at a neutron flux of $2.5 \times 10 \mathrm{n} \cdot \mathrm{cm}^{-2} \cdot \mathrm{s}^{-1}$, and after a waiting time of approximately 7 days the concentrations of $\mathrm{Sm}, \mathrm{U}, \mathrm{Yb}, \mathrm{La}, \mathrm{As}, \mathrm{Sb}, \mathrm{Br}, \mathrm{Sc}, \mathrm{Fe}$ and $\mathrm{Na}$ were similarly determined, with the Na giving a crosscheck with the first analysis. After a two-week delay, the samples were recounted and the concentrations of Nd, Ce, Lu, Ba, Th, Cr, Hf, Sr, Cs, Ni, Th, Sc, $\mathrm{Rb}, \mathrm{Fe}, \mathrm{Co}, \mathrm{Ta}$ and Eu were measured. Once again, the $\mathrm{Sc}$ and $\mathrm{Fe}$ were used to cross-check the second phase of the analysis.

\section{Results and Discussion}

\subsection{Stratigraphy}

A sequence of slope wash and alluvium, interbedded tuffs, and basalt that is presumably younger than $\approx 50,000 \mathrm{yr}$ (HARRIS 1982) provided an opportunity to study weathering and paleosol genesis in a humid tropical setting over a short span of time. The weathered basalt and tuff (units V and IV) shown in Figure 2 are exposed in a gully along the lower flanks of Karisimbi Volcano. Because the two lower units were less highly weathered (based mainly on color differences observed in the field), it was inferred that they had formed over a short span of time followed by a longer period of weathering which produced hues as brown as $10 \mathrm{YR} 6 / 3$. Unit III appeared to be more highly altered with colors of $10 \mathrm{YR} 4 / 6$ indicating that Fehydroxides and oxides might make up the bulk of the weathering products. Because the lower two stratigraphic units consist of pyroclastic/volcanic rock materials that were at least altered to a moderate degree on a flow surface dated at $\approx 50,000 \mathrm{yr}$, it is believed they might have weathered during the drier paleoclimate which accompanied the early stadial of the last glaciation $\approx 50,000-35,000 \mathrm{yr}$ BP) (MAHANEY, 1990).

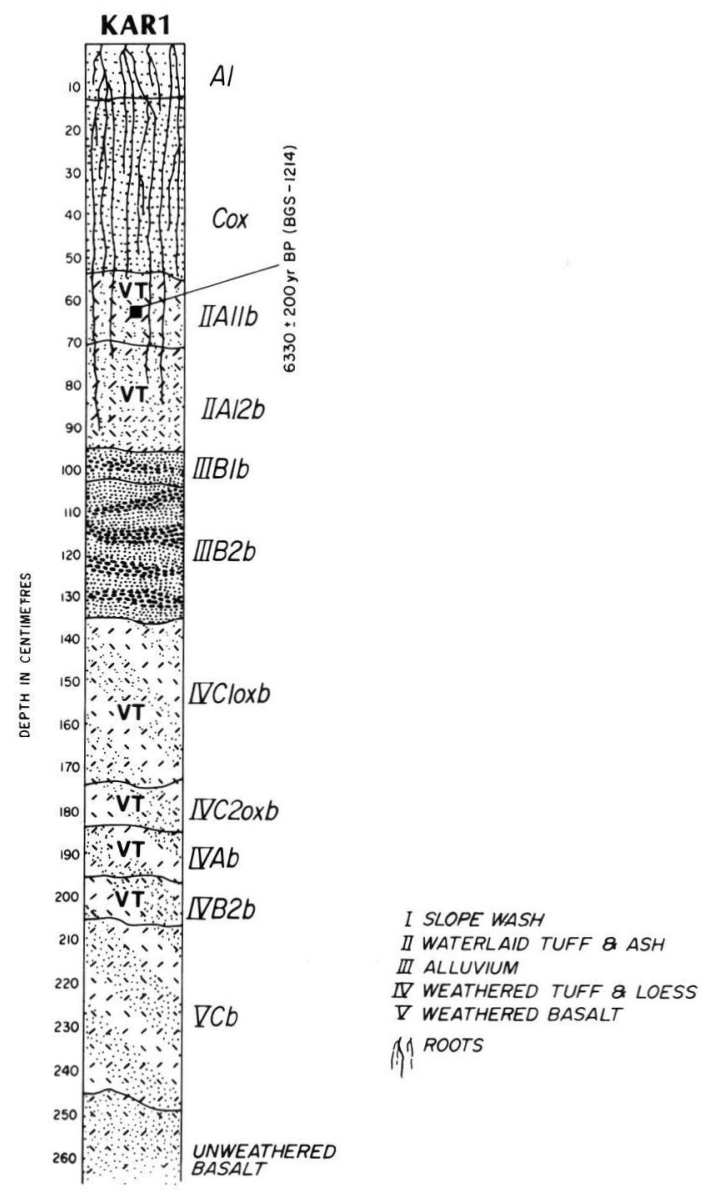

Fig. 2: Stratigraphy of the KAR 1 section, Virunga Mountains. 
The overlying units (I, II and III), consisting of slope wash, alluvium and waterlaid tuff, are considerably younger judging by a ${ }^{14} \mathrm{C}$ date of $6330 \pm 200 \mathrm{yr} \mathrm{BP}$ (BGS - 1214) on charcoal in the IIA $11 \mathrm{~b}$ horizon. Because the precipitation is so high, the particle size so coarse (Table 1), and roots prevalent in the upper two units (Figure 2), it is highly likely that some downward movement of geobiochemical contaminants might have occurred. Units II and III appear to have formed through the interstadial of the last glaciation (Kalambo), the last glacial maximum and early to middle Holocene.

The particle size data in Table 1 show some important trends with respect to clay and silt that bear on the morphogenesis of the two buried paleosols. The lower paleosol [units IV (lower) and V] is considerably higher in silt compared with the weathered bedrock which might be related either to the airfall influx of tuffs and/or loess (glacially-crushed quartz grains indicate aeolian transport of sediments from the Ruwenzori Mountains or some other glaciated area; MAHANEY 1990) from the nearby Ruwenzori Mountains or to reworking of locally derived silt following a major vegetation belt depression during colder stadial climate at or near the end of the last glaciation. Clay translocation in this lower paleosol is only on the order of $1 \%$ indicating a drier paleoclimate that was not conducive to the downward movement of finegrained particles.

The upper paleosol units [(II, III, and IV (upper)] also contain high silt relative to the surface slope wash unit and the weathered bedrock (V). As in the lower paleosol this increase could be related to the emplacement of pyroclastic material or to sorting and reworking of older sediments by streams. The increase of percent clay in the II A $11 \mathrm{~b}$ and IIIB $2 \mathrm{~b}$ horizons indicates a paleosol with considerable power to form clay relative to the underlying paleosol. This increase of clay in the IIIB $2 \mathrm{~b}$ horizon supports the hypothesis of increased downward movement relative to the lower and upper units in the sequence. Because the surface soil is formed in slope wash reworked from nearby slopes covered with pyroclastic sediments it is possible only to point out that higher sand percentages suggest sufficiently high surface run off to move coarse-grained sediments; increasing silt and clay with depth indicate the possibility of some downward movement.

\subsection{Mineralogy}

In order to test the hypothesis of a young $(<50,000$ yr) age for the paleosols in the KAR 1 sequence we analyzed the mineralogy of the $<2 \mu \mathrm{m}$ fraction in each horizon. In the oldest buried paleosol only a trace amount of illite was detected in the IVB2b. Quartz is present in all horizons with moderate amounts in the $\mathrm{VCb}$ and IVB2b horizons diminishing somewhat in the IV Ab horizon. Volcanic feldspars (mainly anorthoclase) are present in small amounts throughout with somewhat lower reflections in the IV A b horizon. Small amounts of hematite were also detected.

The mineralogy of the upper paleosol shows a similar absence of clay minerals with hematite appearing in small to trace quantities as the chief weathering product. Quartz is highest in unit II and in the IVC $20 x b$ (moderate amounts) horizons. Volcanics feldspars are highest in the IIA $11 \mathrm{~b}$, II A $12 \mathrm{~b}$, and IIIB $1 \mathrm{~b}$ horizons, declining somewhat in the lower horizons. The ground soil is noticeably different in that quartz (abundant amounts) and volcanic feldspars (small amounts) are higher than in the two buried paleosols.

Table 1: Particle size ratios for horizons in the KAR 1 paleosol sequence, Virunga Mountains, Northwestern Rwanda

\begin{tabular}{|c|c|c|c|c|}
\hline Horizon & $\begin{array}{l}\text { Depth } \\
(\mathrm{cm})\end{array}$ & $\begin{array}{c}\text { Sand }(\%) \\
(2 \mathrm{~mm}-63 \mu \mathrm{m})\end{array}$ & $\begin{array}{c}\text { Silt }(\%) \\
(63-2 \mu \mathrm{m})\end{array}$ & $\begin{array}{l}\text { Clay }(\%) \\
(<2 \mu \mathrm{m})\end{array}$ \\
\hline
\end{tabular}

\begin{tabular}{lrrrr} 
A 1 & $0-13$ & 82.4 & 11.1 & 6.5 \\
Cox & $13-54$ & 66.8 & 25.5 & 7.7 \\
II A 11 b & $54-70$ & 43.0 & 42.3 & 14.7 \\
II A 12b & $70-94$ & 56.4 & 36.8 & 6.8 \\
IIIB 1 b & $94-103$ & 75.0 & 22.4 & 2.6 \\
IIIB 2 b & $103-135$ & 29.3 & 59.4 & 11.3 \\
IVC1 oxb & $135-173$ & 35.7 & 57.8 & 6.5 \\
IVC2 oxb & $173-182$ & 82.1 & 15.7 & 2.2 \\
IVA b & $182-195$ & 45.7 & 48.9 & 5.4 \\
IVB 2b & $195-205$ & 42.1 & 51.6 & 6.3 \\
VCb & $205-245$ & 65.4 & 32.2 & 2.4 \\
\hline
\end{tabular}


Table 2: Dry colors, $\mathrm{pH}$ and total salts in paleosol sequence KAR 1, Virunga Mountains, Northwestern Rwanda

$\begin{array}{cccc}\text { Hepth } & \text { Drya } & \mathrm{pH} & \text { E. C. } \\ (\mathrm{cm}) & \text { Color } & (1: 5) & \end{array}$

\begin{tabular}{lrlll} 
A 1 & $0-13$ & 10 YR $2 / 22 / 3$ & 5.0 & .28 \\
Cox & $13-54$ & 10 YR 4/3 4/2 & 5.5 & .05 \\
II A 11b & $54-70$ & 10 YR 3/3 & 5.3 & .09 \\
II A 12b & $70-94$ & 10 YR 3/4 & 5.4 & .05 \\
IIIB 1 b & $94-103$ & 10 YR 5/3 & 5.4 & .05 \\
IIIB 2b & $103-135$ & 10 YR 4/6 & 5.5 & .04 \\
IVC 1 oxb & $135-173$ & 10 YR 7/3 & 5.5 & .06 \\
IV C2 oxb & $173-182$ & 10 YR 6/3 & 5.8 & .04 \\
IV A b & $182-195$ & 10 YR 3/4 & 5.8 & .08 \\
IVB2b & $195-205$ & 10 YR 6/3 & 5.8 & .04 \\
VCb & $205-245$ & 10 YR 6/3 5/3 & 5.8 & .07 \\
\hline
\end{tabular}

a Colors follow Oyama and Takehara (1970)

Also, pyroxene which exists in trace amounts in the buried paleosols is higher in the ground soil. Because quartz is relatively rare in the volcanic rocks of the Virunga Mountains it may signal airfall influx, perhaps, from the nearby Ruwenzori Mountains. The plagioclase feldspars are noticeably higher in the A 1 horizon when compared with the lower paleosols and with the Cox horizon indicting they are being contributed from fresh outcrops up slope. Although it may be inappropriate to compare the $<2 \mu \mathrm{m}$ fraction mineralogy with the $<2 \mathrm{~mm}$ fraction geochemistry, elevated $\mathrm{Na}$ and $\mathrm{K}$ concentrations are also observed in the A 1 and Cox horizons (see Table 3).

\subsection{Soil Chemistry}

Soil colors, $\mathrm{pH}$ and total salts (Table 2) were studied to determine whether they could be used to differentiate the three units. The $\mathrm{pH}$ trends in the upper two units show slight increases with depth; the lower unit is uniform. These data indicate slight movement of $\mathrm{H}^{+}$ions in the upper two units and none in the lower unit. The data for total salts reveal only slightly higher concentrations in the $\mathrm{A}$ and $\mathrm{Ab}$ horizons relative to the other horizons. Based on the geochemical data discussed later the salts present must be $\mathrm{NO}$ and $\mathrm{SO}$ rather than $\mathrm{Cl}$. The soil colors shown in Table 2 are all in the $10 \mathrm{YR}$ range suggesting younger material that is not highly altered. These yellowish red colors are compatible with the liberation of moderate amounts of goethite and minimal to trace amounts of hematite. The color trends suggest that the IIIB $2 \mathrm{~b}$ horizon might contain the highest concentration of liberated oxides, hydroxides and clay minerals. Table 3 confirms this prediction with its highly elevated Fe content in the III B $2 \mathrm{~b}$ horizon.

\subsection{Geochemistry}

The chemical analysis data for the KAR 1 section, which are listed in Table 3, show considerable variability. Some of the variation may be associated with different lithological materials or with weathering, paleoclimate and/or drainage. Because $\mathrm{Na}$ and $\mathrm{K}$ are the most mobile of the major elements their depletion in the tuff/ash, alluvium, and lower tuff/loess horizons indicates that weathering effects were especially prominent in forming these Inceptisols. This supposition is born out by a check of the inter-element correlations using Pearson correlation coefficients, which show that $\mathrm{Na}$ and $\mathrm{K}$ are highly positively correlated. Both are positively correlated with $\mathrm{Rb}$ and are negatively correlated with $\mathrm{Sc}, \mathrm{T}, \mathrm{Cr}, \mathrm{Ni}, \mathrm{Br}$ and $\mathrm{Cs}$.

Four other correlation groups including major elements are also apparent. Magnesium, Ca, Mn, Co, V, $\mathrm{Sr}, \mathrm{Cl}$, and $\mathrm{Ba}$ are all highly positively correlated and are negatively correlated with $\mathrm{As}, \mathrm{Sb}, \mathrm{Br}$, the rare earth elements (REEs), Hf, Ta, Th, and U. Aluminium is positively correlated with As, $\mathrm{Sb}$, the REEs, Hf, $\mathrm{Ta}$, Th, and $\mathrm{U}$, and is negatively correlated with $\mathrm{Cr}$, Sc, V, Ti, Mn, and Co. Titanium, Sc, V, Cr, Ni, and $\mathrm{Mn}$ are all highly positively correlated and are negatively correlated with As, Sb, REEs, Hf, Th, and U. Iron does not correlate with any of the other major elements, although it is negatively correlated with $\mathrm{Sb}$, the REEs, Hf, Ta, Th, and U. 


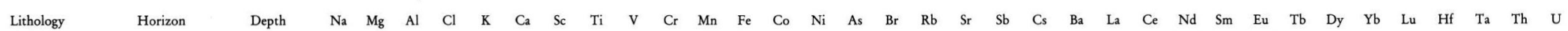

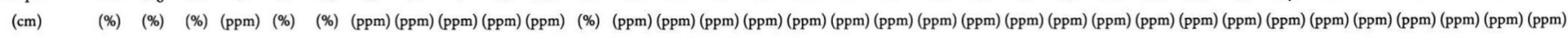

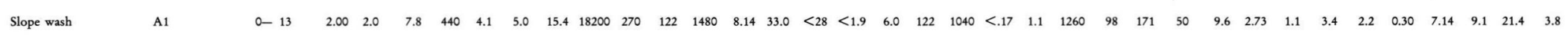

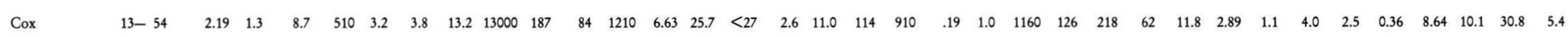

\begin{tabular}{|c|c|c|c|c|c|c|c|c|c|c|c|c|c|c|c|c|c|c|c|c|c|c|c|c|c|c|c|c|c|c|c|c|c|c|c|c|}
\hline Tuff $\&$ ash & IIA11b & $54-70$ & 1.07 & 1.1 & 6.6 & 240 & 1.7 & 2.9 & 14.6 & 15200 & 208 & 167 & 1020 & 6.21 & 26.2 & $<32$ & $<2.1$ & 10.9 & 81 & 490 & $<.18$ & 2.4 & 870 & 99 & 189 & 51 & 8.9 & 2.41 & 1.1 & 3.7 & 2.0 & 0.33 & 7.58 & 11.4 & 24.8 & 4.9 \\
\hline & IIA12b & $70-94$ & 0.80 & 1.0 & 7.7 & $<200$ & 1.5 & 2.3 & 14.9 & 17800 & 250 & 154 & 765 & 4.77 & 15.1 & $<29$ & 3.3 & 16.3 & 62 & 300 & $<.17$ & 1.9 & 730 & 101 & 173 & 68 & 10.8 & 2.86 & 1.1 & 4.3 & 1.7 & 0.24 & 7.90 & 15.6 & 30.1 & 7.1 \\
\hline \multirow[t]{2}{*}{ Alluvium } & IIIB1b & 94-103 & 0.82 & 1.1 & 8.8 & $<200$ & 1.5 & 2.6 & 19.6 & 19300 & 299 & 195 & 605 & 4.76 & 13.6 & 38 & 3.1 & 15.1 & 53 & 340 & $<.18$ & 1.0 & 670 & 123 & 227 & 54 & 13.4 & 3.75 & 1.4 & 5.5 & 1.8 & 0.28 & 9.75 & 16.0 & 32.8 & 7.6 \\
\hline & IIIB $2 b$ & $103-135$ & 1.42 & 0.5 & 8.4 & $<250$ & 2.7 & 1.6 & 9.5 & 9000 & 178 & 47 & 639 & 14.9 & 15.7 & $<31$ & 4.3 & 10.2 & 103 & 420 & $<.17$ & 0.7 & 810 & 113 & 199 & 57 & 9.7 & 2.93 & 1.1 & 4.2 & 1.8 & 0.31 & 8.99 & 11.7 & 35.8 & 6.7 \\
\hline \multirow[t]{4}{*}{ Tuff $\&$ loess } & IVCloxb & $135-173$ & 3.09 & 0.6 & 10.4 & $<200$ & 4.5 & 1.2 & 6.5 & 5700 & 79 & 29 & 254 & 2.77 & 5.4 & $<25$ & 5.2 & 9.1 & 179 & 270 & .36 & 1.2 & 460 & 90 & 180 & 56 & 10.1 & 2.51 & 1.1 & 4.7 & 1.7 & 0.37 & 15.3 & 15.6 & 63.9 & 10.9 \\
\hline & IVC2oxb & $173-182$ & 1.77 & 0.9 & 9.6 & 530 & 3.5 & 3.3 & 10.2 & 12900 & 195 & 53 & 1130 & 7.88 & 22.4 & $<24$ & 2.1 & 3.2 & 96 & 850 & $<.15$ & 0.4 & 1170 & 111 & 197 & 57 & 10.0 & 2.75 & 1.0 & 3.9 & 2.1 & 0.32 & 8.98 & 9.7 & 31.3 & 4.8 \\
\hline & IVAb & $182-195$ & 1.18 & 0.4 & 10.3 & $<200$ & 2.1 & 1.0 & 8.9 & 7700 & 125 & 45 & 354 & 3.98 & 16.1 & $<27$ & 3.6 & 17.4 & 73 & 340 & .34 & 0.5 & 640 & 215 & 330 & 87 & 15.8 & 2.81 & 1.5 & 7.3 & 3.0 & 0.48 & 13.3 & 12.2 & 59.9 & 14.5 \\
\hline & IVB2b & 195-205 & 0.85 & 0.57 & 9.7 & $<200$ & 2.1 & 0.8 & 11.5 & 16400 & 139 & 89 & 230 & 2.36 & 8.7 & $<29$ & 3.4 & 9.5 & 154 & 150 & .30 & 3.8 & 750 & 178 & 370 & 95 & 14.9 & 2.43 & 1.8 & 7.4 & 3.0 & 0.47 & 12.8 & 22.0 & 56.9 & 13.4 \\
\hline Basalt & $\mathrm{vCb}$ & $206-245$ & 2.20 & 0.9 & 10.9 & $<350$ & 3.2 & 3.1 & 11.4 & 12600 & 178 & 45 & 733 & 4.88 & 16.3 & $<25$ & 2.2 & 6.9 & 95 & 770 & $<.16$ & 0.4 & 1260 & 94 & 182 & 59 & 10.5 & 2.90 & 1.2 & 3.8 & 2.3 & 0.32 & 11.2 & 11.9 & 41.0 & 6.4 \\
\hline
\end{tabular}


If it is possible to relate these geochemical correlation findings to the specific mineralogy of the section, then there are significant quantities of at least five primary minerals combined to make up the sediments in the KAR 1 section.

The $\mathrm{Na}$ and $\mathrm{K}$ are depleted in the tuff and ash, in the alluvium, in the lower two horizons (IV Ab and IVB $2 \mathrm{~b}$ ) in the tuff and loess, indicating major leaching of these materials during or after their formation. The $\mathrm{Mg}, \mathrm{Ca}$, et al.-rich materials are highest in the slope wash material, in the IVC 2 oxb horizon in the tuff and loess, and in the weathered basalt horizon (VCb). Aluminium and its associated elements tend to increase in concentration downward through the section, with exceptionally high levels in the IVC 1 oxb horizon in the tuff and loess. Titanium and the associated transition metals tend to be depleted in the IIIB $2 \mathrm{~b}$ horizon in the alluvium and in the next lower IVC 1 oxb horizon in the tuff and loess, and in the IVAb horizon in the tuff and loess. They therefore tend to be depleted in the highest silt-containing units of the section, implying that they may be associated with material in either the sand or the clay fractions of the soils.

The distribution of Fe with depth shows trends that are probably related to paleoclimate and time of exposure to subaerial weathering processes. The highest $\mathrm{Fe}$ content, by far is found in the IIIB 2 b horizon in the alluvium. This high $\mathrm{Fe}$ content could result from differences in parent materials or from relative movement (depletion/enrichment) caused by different paleoclimates. The Fe levels are next highest in the slope wash material, and in the IVC 2 oxb horizon in the tuff and loess. If one compares the two buried paleosols [(II, III, and IV (upper)) and (IV (lower) and $\mathrm{V})]$, it appears that the lower one was exposed for either a shorter time or that it formed in a paleoclimate with less available moisture than the upper one. It is likely that some of the Fe is organically complexed into a soluble form (see paleosol colors in Table 2 ), which allowed it to move downward in the upper buried paleosol, eventually enriching the buried B horizon. If this hypothesis is correct one is dealing with a considerably stronger paleoclimate in units II, III and IV (upper) compared with IV (lower) and V. The Fe data tend to support the notion that the lower paleosol formed during one of the stadial intervals during the last glaciation, while the upper paleosol formed mainly during the Kalambo Interstadial, Last Glacial Maximum, and early postglacial period up to around $6330 \pm 200 \mathrm{yr}$ BP (BGS-1214). While paleoecological data are scarce from the East African mountains, the period from $8000-4000 \mathrm{yr}$ BP is considered to have been wetter and warmer than the early and later Holocene (MAHANEY 1988, 1989).

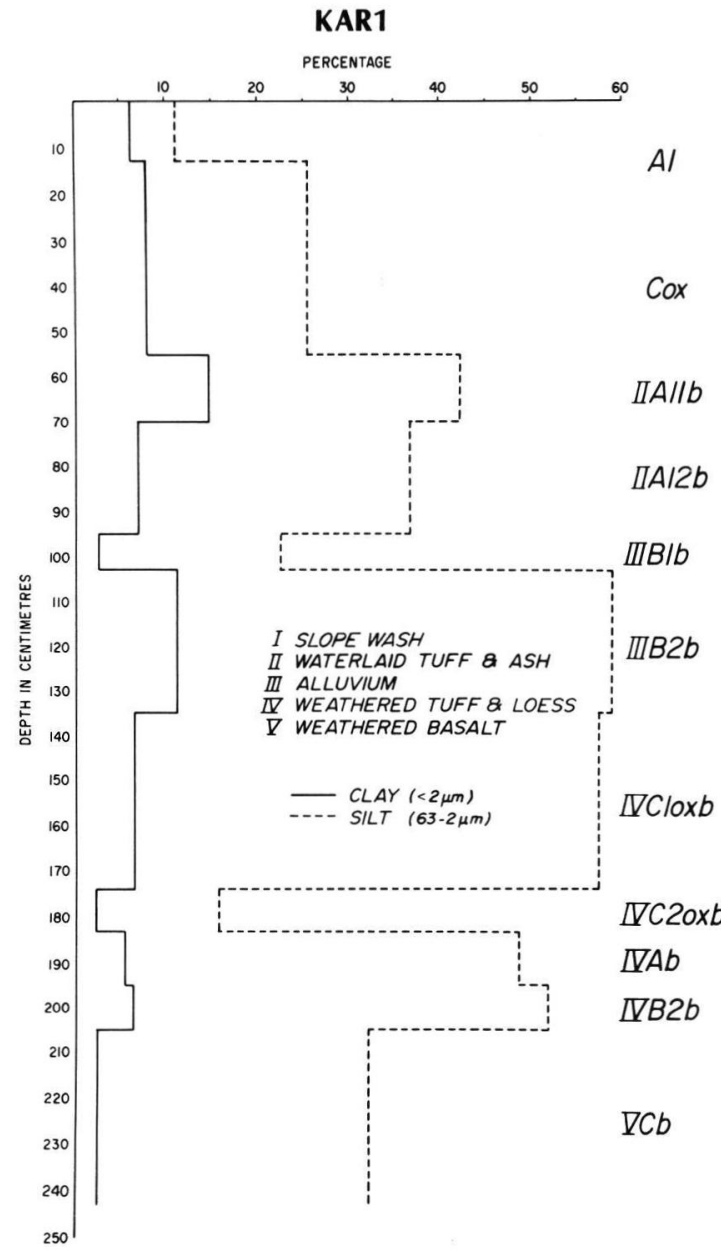

Fig. 3: Clay and silt distributions with depth in the KAR 1 section.

The high concentrations of $U$ and Th through the surface soil and buried paleosols support the scanty information on radioactive basalts discovered during a geophysical survey in the Virunga Mountains during the early 1980's (ANTUN \& MAGNEE 1983). Levels of U and Th are highest in the tuff and loess.

A chondrite normalized plot of the rare earth elements for the sample suite shows relative uniformity both in curve shape and in magnitude (see Figure 4). In this figure, the outermost data points are shown with solid black lines and the profiles for representative samples A 1, Cox, and IVAb are included for detail.

The relative uniformity of the pattern indicates that the $<2 \mathrm{~mm}$ soil (paleosol) fraction samples were formed from material of similar magmatic composition, probably over a short geological time span. 


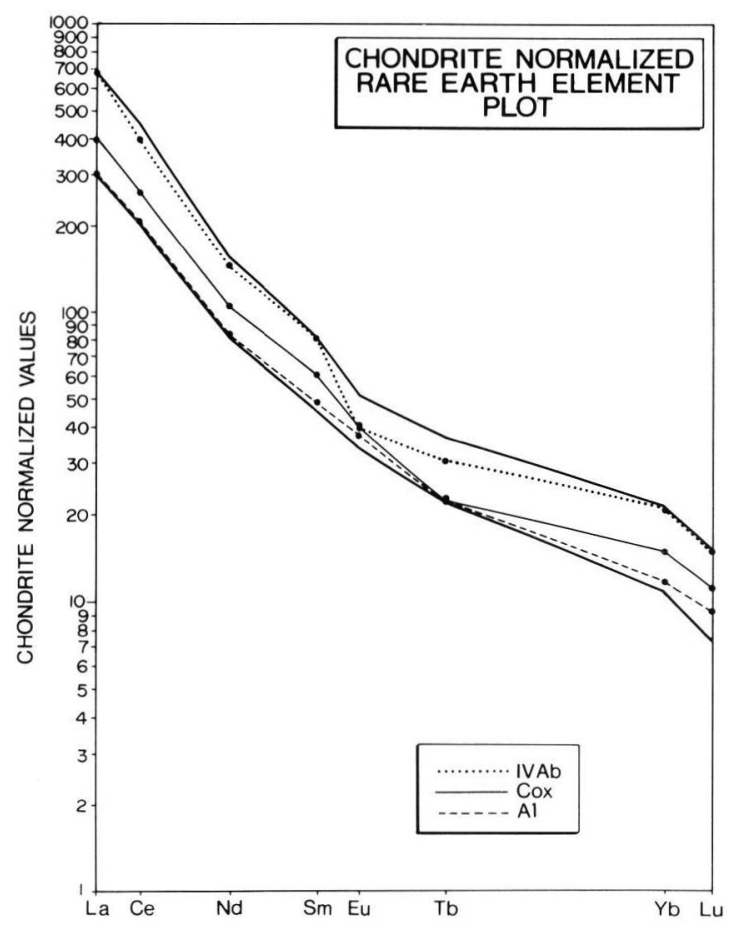

Fig. 4: Chondrite-normalized values for rare-earth elements in selected paleosol samples from the KAR 1 section, Virunga Mountains.

\subsection{Paleomagnetism}

In July, 1987, samples for paleomagnetic analysis were collected between Visoke and Karisimbi volcancoes (Figure 1). In total, 73 polycarbonate cubes $(2 \mathrm{~cm} \times$ $2 \mathrm{~cm} \times 2 \mathrm{~cm}$ ) were inserted into the sediments using hand pressure, and where necessary through gentle tapping with a rubber mallet. In addition, several blocks of unweathered vesicular basalt were marked and collected in the field, and cored in the laboratory using a bench drill. Analysis was carried out using a DSM-1 spinner magnetometer in the paleomagnetic laboratory at the Pacific Geoscience Center.

Magnetization data for the Karisoke sediments fall into three types: (a) single component magnetization (specimen b, Figure 5); (b) multicomponent magnetization (specimen c, Figure 5); and (c) incoherent magnetization (specimens a and d, Figure 5).

Approximately one third of the pilot specimens (Figure 5) collected from the Karisoke sediments can be characterized as a Type A magnetization, that is, they are single component (except for a small present earth's field component) and their magnetization values after stepwise demagnetization plot as a straight line that reaches nearly to the origin of an orthogonal projection. Another third of the pilot specimens can be characterized as a type B magnetization, that is, they are multicomponent, and after stepwise demagnetization, one of these components shows
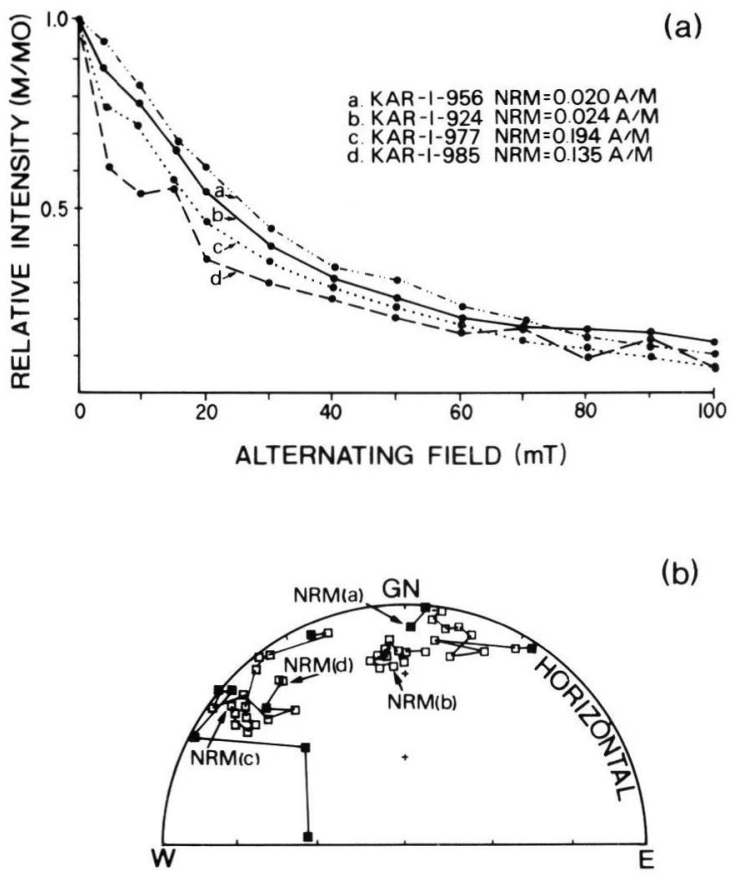

(b)

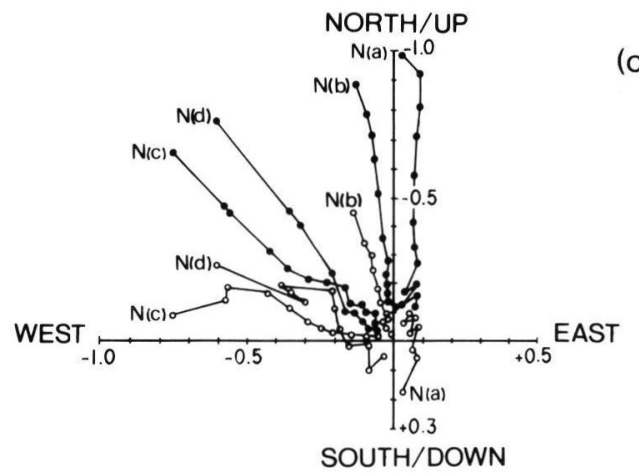

Fig. 5: Magnetization behavior of pilot specimens from normally magnetized unconsolidated sediments following stepwise alternating field (af) demagnetization. Natural remanent magnetization is indicated by letters

NRM. Normalized magnetization ( $\mathrm{M} / \mathrm{MO}$ ) versus af

demagnetization (a), and direction changes during a demagnetization projected on a lower hemisphere equal area stereographic projection (b) where open squares [ $\square_{1}$ and solid squares [ $\mathbf{\square}$ ] represent negative and positive inclination respectively, and orthogonal vector projections (c), with respect to present horizontal, where solid circles [] refer to N/S axis (horizontal plane) and open circles [00] to Up/Down axis (vertical plane). 
magnetization values which plot as a straight line that reaches nearly to the origin of an orthogonal projection. The remainder of the pilot specimens can be characterized as a type $\mathrm{C}$ magnetization, that is, they show incoherent magnetization values with stepwise demagnetization. The basalts beneath the Quaternary sediments show a single component (Type A) magnetization (Figure 6).

Type $\mathrm{C}$ magnetizations are recorded in sediments at $0-50$ and $140-180 \mathrm{~cm}$ below the surface (Figure 7). These are zones containing abundant grit and pebble size tuff particles. The coarser fraction of these sedi-
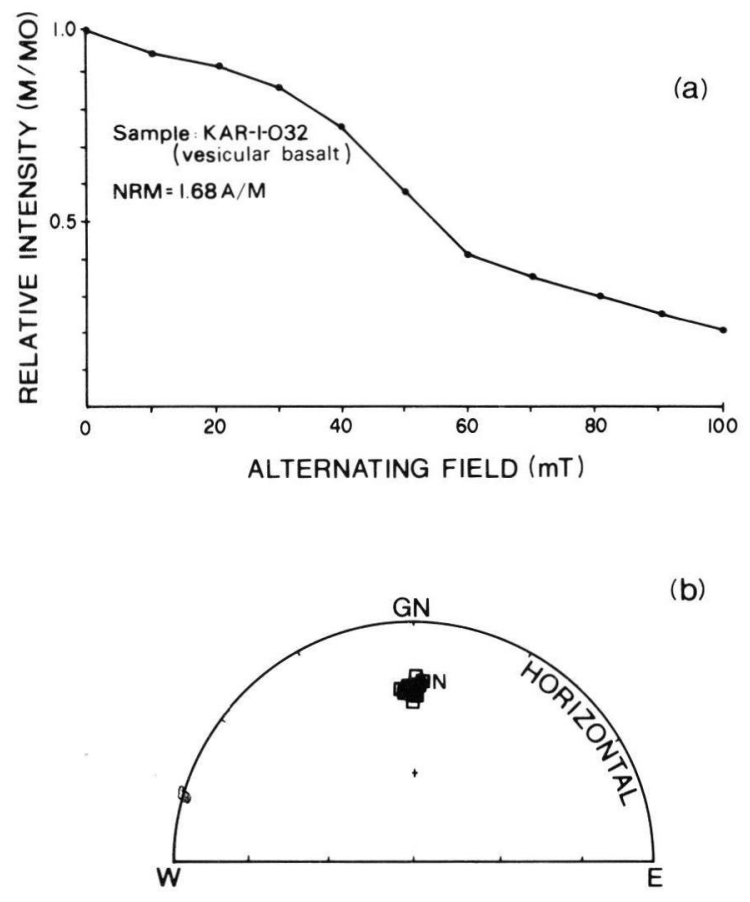

(b)

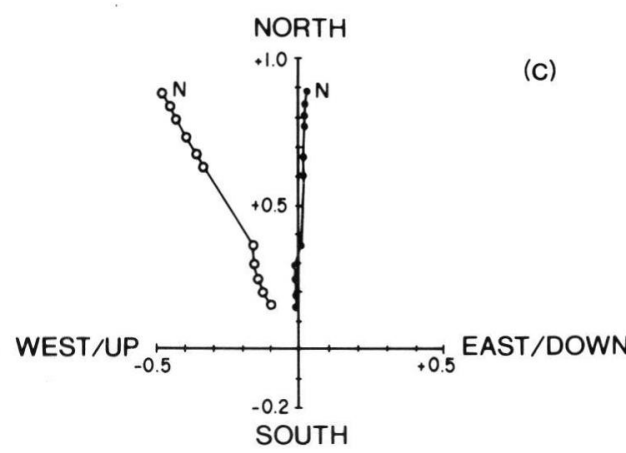

Fig. 6: Magnetization behavior of a pilot specimen from the normally magnetized vesicular basalt found directly beneath the unconsolidated sediments. Symbols as in Figure 1. ments is either too large for alignment in an ambient magnetic field and hence will show random magnetization directions, or was only partially aligned. In either case, the coarser fraction of the sediments may entirely or partially mask the dipole magnetization of the finer matrix fraction. In these sediments, stepwise demagnetization did not produce a clear direction with an end point near the origin of the orthogonal plot.

As can be seen from Figure 7, the inclination and declination profiles reveal a suite of normally magnetized sediments. The inclination profile shows a somewhat noisy record with values which in places are considerably steeper than would be expected for an equatorial sampling latitude. Inclination values at the equator should essentially be zero. Some of the large swings in declination and inclination are associated with low $\mathrm{K}^{\star}$ values (Table 4 ), where $\mathrm{K}^{*}$ is a measure of the degree of internal consistency within a sample, and are thus suspect. $\mathrm{K}^{*}$ values greater than 10 are considered acceptable. The magnetization profile shows a rather consistent pattern of progressive waxing and waning of the sample intensity which in all likelihood is a true depiction of field behavior. This record would seem to indicate that the 2.4 meters of unconsolidated sediments at Karisoke were deposited over a period of several thousand years.

\section{Conclusions}

Two buried paleosols and one surface soil display different degrees of development compatible with genesis in: a) a drier stadial paleoclimate, b) wetter interstadial and early to middle postglacial paleoclimate, and c) drier later Holocene climate. The lithologic sequence of sediments supports the paleoclimatic interpretation in that alluvium (unit III) was emplaced between short - lived episodes of pyroclastic activity that emplaced tuffs (units IV and II). If the ${ }^{14} \mathrm{C}$ date of $6300 \pm 200 \mathrm{yr} \mathrm{BP}$ is correct, it would appear the surface slope wash sediments buried the II A $11 \mathrm{~b}$ horizon during the middle Holocene when the paleoclimate is known to have been wetter. However, in all likelihood the upper paleosol dates from the Kalambo Interstadial of the last glaciation.

The geochemistry of this sequence supports the notion of more intense weathering and translocation in the middle paleosol. In particular lower $\mathrm{Na}$ and $\mathrm{Ca}$ concentrations indicate more intense drainage and the data for Fe suggest displacement from the $\mathrm{Ab}$ complex into the B2b horizon in the middle paleosol. The data for U-Th indicate that radioactivity in the local bedrock is caused by both elements. 

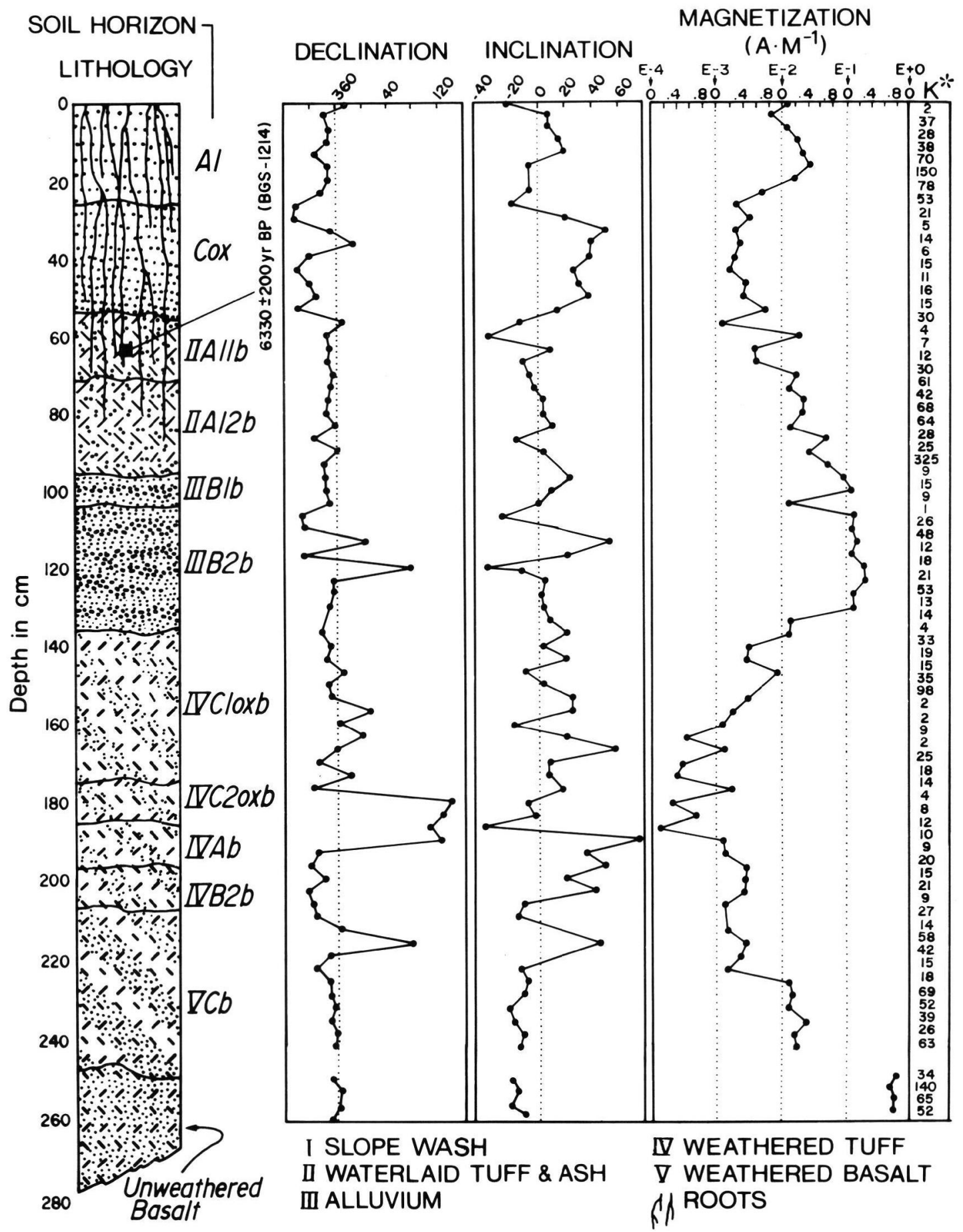
$\mathrm{K}^{*}$ precision parameter (Fisher, 1953 )
where values greater than io are
acceptable.

Fig. 7: Stratigraphic and paleomagnetic profiles for Site KAR 1, Virunga Mountains, Rwanda. Magnetization values for all samples are at 10 militesla $(\mathrm{mT})$ demagnetization.

Units of inclination and declination are in degrees; units of magnetization are in amperes per meter $A \cdot M^{-1}$. 
Table 4: Mean Remanent Magnetization Directions

\begin{tabular}{|c|c|c|c|c|c|c|c|c|c|c|c|c|}
\hline \multirow[b]{2}{*}{ Site } & \multirow[b]{2}{*}{ Thickness } & \multirow[b]{2}{*}{ Lithology } & \multirow[b]{2}{*}{ Age } & \multirow[b]{2}{*}{ Polarity } & \multirow[b]{2}{*}{$\mathrm{N}$} & \multirow[b]{2}{*}{ M } & \multirow[b]{2}{*}{$\mathrm{D}$} & \multirow[b]{2}{*}{1} & \multirow[b]{2}{*}{$\mathrm{K}$} & \multirow[b]{2}{*}{$\alpha 95$} & \multicolumn{2}{|c|}{ Pole } \\
\hline & & & & & & & & & & & Lat. & Long. \\
\hline Karisoke 1 & $250 \mathrm{~cm}$ & $\begin{array}{l}\text { volcanic } \\
\text { tuff \& ash }\end{array}$ & Brunhes & $\mathrm{N}$ & 73 & .03 & 35 & -0.5 & 11 & 7 & $81^{\circ} \mathrm{N}$ & $303^{\circ}$ \\
\hline Karisoke 1 & $250 \mathrm{~cm}^{+}$ & vesicular & Brunhes & $\mathrm{N}$ & 4 & 1.0 & 360 & -23 & 298 & 5 & $80^{\circ} \mathrm{N}$ & $206^{\circ}$ \\
\hline
\end{tabular}

$\mathrm{N} \quad=$ number of specimens

$\mathrm{M} \quad=$ average intensity of magnetization $\left(\mathrm{AM}^{-1}\right)$

$\mathrm{D} \quad=$ average declination (degrees)

$\mathrm{I} \quad=$ average inclination (degrees)

$\mathrm{K} \quad=$ precision parameter (FISHER, 1953)

$\alpha 95=$ radius of the cone of $95 \%$ confidence about the resultant vector

The Karisoke sediments are for the most part stably magnetized and record a normal dipole field. The zones of coarse sediment generally reveal incoherent magnetization directions which are nevertheless all normal. Mean remanent magnetization directions indicate a local field with an inclination of -0.5 degrees and a declination of 35 degrees indicating that a normal dipole field existed at the time of deposition of these sediments. The underlying vesicular basalt is likewise normally magnetized.

\section{Acknowledgements}

The authors thank the Natural Sciences and Engineering Research Council of Canada for financial support to the SLOWPOKE Reactor Facility and to WCM (grant A 9021) and RWB (Grant A 0581). They also thank the Digit Fund and D. P. Watts, former Director of the Karisoke Research Center for use of facilities, accommodation, and for assistance in working around mountain gorilla groups in the Karisoke Research Area. Field work was authorized by l'office Rwandaise du Tourisme et des Parcs Nationaux. Laboratory analyses were completed at the SLOWPOKE Reactor Facility, University of Toronto, at the Geomorphology and Pedology Laboratory, Geography Department, Atkinson College, York University, and at the Pacific Geoscience Centre, Energy Mines and Resources, Vancouver, B. C.

\section{References}

Antrum, P. \& Magnee, L. (1983): Champ Volcanique des Birunga (map of bedrock in the Virunga Mountains). Museum of Middle Africa, Tervuren, Belgium.

BiRKelAND, P. W. (1984): Soils and Geomorphology: N. Y., 372 p.; Oxford.
BouYoucos, G. J. (1962): Hydrometer method improved for making particle size analyses of soils. - Agron. Jour. IV. 54 , p. $464-465$.

BOWER, C. A. \& Wilcox, L. V. (1965): Soluble salts. in BLACK, C. A., ed., Methods of Soil Analysis. - Madison, Wisc., Amer. Soc. Agron.: p. 933-951.

COE, M. J. (1967): The ecology of the Alpine zone of Mount Kenya. - The Hague, Junk, 136 p.

DAY, P. (1965): Particle fractionation and particle size analysis. - in BLACK, C. A. ed., Methods of Soil Analysis. - Madison, Wisc., Amer. Soc. Agron., p. $545-567$

Fisher, R. A. (1953): Dispersion on sphere. - Proc. of the Royal Soc., A 217, 295-305, London.

FoLK, R. L. (1968): Petrology of Sedimentary Rocks. Austin, Texas, Hemphill Press, 170 p.

Fossey, D. (1982): Gorillas in the Mist. - 326 p., Houghton Mifflin Co., Boston Mass. Houghton Mifflin.

HANCOCK, R. G. V. (1978): Some aspects of the analyses of ancient artifacts by neutron activation analysis. - Jour. of Internatl. Inst. of Conservation - Candadian Group, 3 p.; Ottawa, Ont., 21-27.

- (1984): On the source of clay used for Cologne Roman pottery. - Archaeometry 26, p. 210-217; Oxford UK.

Harris, N. (1982): The Virunga Volcanoes. - unpublished notes on file at the Karisoke Research Centre, Virunga Mountains.

Hedberg, O. (1964): Features of Afroalpine Plant Ecology. - Almquist and Wiksells, 144 p.; Uppsala.

Mahaney, W. C. (1981): Paleoclimate reconstructed from paleosols: evidence from East Africa and the Rocky Mountains. - in MAHANEY, W. C. ed., Quaternary Paleoclimate. - Geobooks, p. 227-247; Norwich.

- (1988): Holocene glaciations and paleoclimate on Mount Kenya, East Africa: Quaternary Science Reviews, 7, 211-225. 
MahaneY, W. C. (1989b): Quaternary geology of Mount Kenya. - in MaHANEY, W. C., ed., Quaternary and environmental research on East African mountains. 121-140; Balkema, Rotterdam.

- (1990): Glacially-crushed quartz grains in late Quaternary deposits in the Virunga Mountains, Rwanda indicators of wind transport from the north. - Boreas, in press.

- (1990): Cadre stratigraphique géochronologique de la fin du Pleistocène et de l'Holocène dans le régions montagneuses de l'Est Africain. - L'Anthropologie, 2, 211-228; Paris.

— \& BOYER, M. G. (1986): Microflora distributions in paleosols: a method for calculating the validity of radiocarbon-dated surfaces. - Soil Science, 142(2), p. $100-107$.
MERCIER, A. (1984): Visité de la valleé à fond plateau entre le Bisoke et le Karisimbi. - Unpublished field notes.

Oyama, M. \& Takehara, H. (1970): Revised Standard Soil Color Charts. - Japan Research Council for Agriculture, Forestry and Fisheries.

Soll SuRvey Staff (1951): Soil Survey Manual. - Washington, D. C., U. S. Department of Agriculture Handbook 18, U. S. Government Printing Office, 503 p.

- (1975): Soil Taxonomy: Washington, U. S. Government Printing Office, $754 \mathrm{p}$.

WhitTig, L. D. (1965): X-ray diffraction techniques for mineral identification and mineralogical composition. - in BLACK, C. A., ed., Methods of Soil Analysis. Amer. Soc. Agron., p. 671-696; Madison, Wisc.

Manuscript accepted 11. November 1990 